\title{
Introducing and applying a modified AHP (Analysis Hierarchy Process) to analyse productivity at the construction site.
}

\author{
$\underline{\text { Mi Na Lee }}{ }^{1}$, Kye Young Lee ${ }^{2}$, Soon Wook Kwon ${ }^{3 *}$, Jung Hwan Shin ${ }^{4}$ \\ 1 Department of u-City Design and Engineering, Department of Civil, Architectural and En- \\ vironmental System Engineering, Sungkyunkwan University, Suwon, Korea \\ ${ }^{2}$ Construction Equipment Research Institute, Samsung C\&T Corporation, Korea \\ ${ }^{3}$ Department of Civil, Architectural and Environmental System Engineer- \\ ing ,Sungkyunkwan University, Suwon, Republic of Korea \\ ${ }^{4}$ Department of u-City Design and Engineering, Sungkyunkwan University, Suwon, Korea \\ *Corresponding author (swkwon@skku.edu)
}

\begin{abstract}
Purpose Improvement of on-site productivity has been a very important issue in the construction industry and construction companies struggle to overcome this problem. In Korea, a construction company considered adopting a newly developed construction tool from other countries. The company would like to measure productivity before and after adopting the tools. The objective of this study is to understand productivity analysis for selected advanced construction tools in the construction site where the tools were used. This study is aimed at valuation of productivity as a result of the application of the existing and advanced tools using analysis hierarchy process (AHP) which is a representative survey method. Method For this study, several surveys were conducted to obtain from the managers' and practitioners' viewpoint. By analyzing this, a tool-guiding method was developed and a construction tool application was selected before buying or adopting these tools. AHP is useful for understanding the complex structures which combine the macro-view of manager and the micro-view of practitioner. So in this study we used the AHP and evaluated the productivity. Results \& Discussion Through survey and pairwise comparison, we obtained information on the evaluation factors that the manager focused on. Also, the practitioner evaluation was derived from the survey on a maximum scale of 7 points. This way the existing and an adapted tool may be compared. Introducing and using the advanced tools, manager and practitioner succeeded in identifying priority factors.
\end{abstract}

Keywords: productivity, work-sampling, AHP (Analysis Hierarchy Process), construction tool

\section{INTRODUCTION}

Productivity is used as a tool to measure real production activities in all industrial areas. Productivity is defined as the ratio of input and output when products are manufactured for a certain period of time using a production system.

The construction industry is labor-intensive, its work is performed largely outside, a large number of businesses in the area engage in a project together; as a result, the industry has many factors to make it hard to evaluate its productivity. Therefore, application of the concept of productivity to the industry is not so simple; therefore labor productivity is commonly used.

Factors that influence on construction productivity are broadly divided into two. They are internal influence factors that may be controlled within a production system and external influence factors with the opposite concept. Enhancement in productivity is mainly achieved by improving internal influence factors.
Internal influence factors are divided into hard factors-product, technology, materials, energy, plant, and equipment-and soft factors-construction controls, work methods, people, organization, systems, and management style. Productivity is enhanced through the removal and improvement of inappropriate internal influence factors.

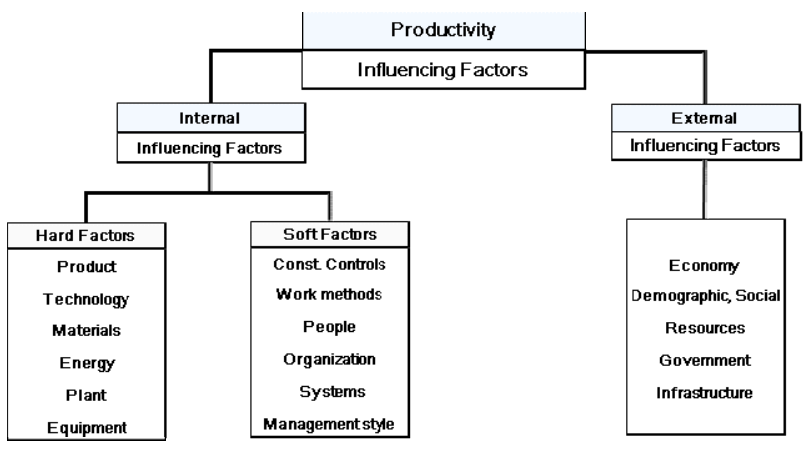

Fig. 1. Factors that Influence Productivity of the Construction Industry 
High productivity in advanced countries' construction sites were judged to result from efficient application of advanced construction tools to unit work. Here, advanced construction tools mean high-performance work tools, small equipment, or safety goods that have not been applied to sites in Korea but are in common use in advanced countries.

Accordingly, this study introduced advanced construction tools for productivity enhancement through improvement in internal influence factors. Further, this study collected and analyzed opinions of managers and workers at construction sites using a questionnaire, aimed at a measure to select and utilize advanced construction tools.

\section{METHOdOLOGY}

A comprehensive evaluation of advanced construction tools was made, with a structure of combining managers' macroscopic insights and managers' microscopic opinions. The questionnaire has two parts of calculating mangers' weight and evaluating workers' degree of satisfaction. Analysis hierarchy process (AHP), one of multi-criteria decision making methods, was used for this purpose.

AHP is a technique presented by Thomas. L. Satty and one of decision support systems. This is widely used in multi-criteria decision making that includes both quantitative and qualitative elements; this method has enabled comprehensive evaluation and integration of quantitative and qualitative elements. AHP classifies decision making elements into goal, criteria, and alternatives, and structuralizes and systemizes such elements. In particular, one of the most significant characteristics of AHP is to provide hierarchy to a complicated problem and divide its factors into major factors and sub-factors, make a pairwise comparison of these factors, derive their weights, and prioritize them.

Table 1. Pairwise Comparison

\begin{tabular}{|c|c|c|c|c|c|}
\hline & A1 & A2 & A3 & A4 & A5 \\
\hline A1 & 1 & A1/A2 & A1/A3 & A1/A4 & A1/A5 \\
\hline A2 & A2/A1 & 1 & A2/A3 & A2/A4 & A2/A5 \\
\hline A3 & A3/A1 & A3/A2 & 1 & A3/A4 & A3/A5 \\
\hline A4 & A4/A1 & A4/A2 & A4/A3 & 1 & A4/A5 \\
\hline A5 & A5/A1 & A5/A2 & A5/A3 & A5/A4 & 1 \\
\hline
\end{tabular}

Under this pairwise comparison, the value from comparison between the same items is 1.0 and a reverse comparison results in a reciprocal number. Further, decision making is made by verifying consistency of the calculated weights. Thanks to such advantages, AHP is one of the most widely used techniques among exiting decision making methods. This study modified and applied using AHP. The questionnaire for the calculation of managers' weights aimed at analyzing managers' judgments regarding the introduction of advanced construction tools were classified as Level 1 and pairwise comparison of them was made. The questionnaire on workers aimed at analyzing workers' evaluation values who use advanced construction tools was classified as Level 2.

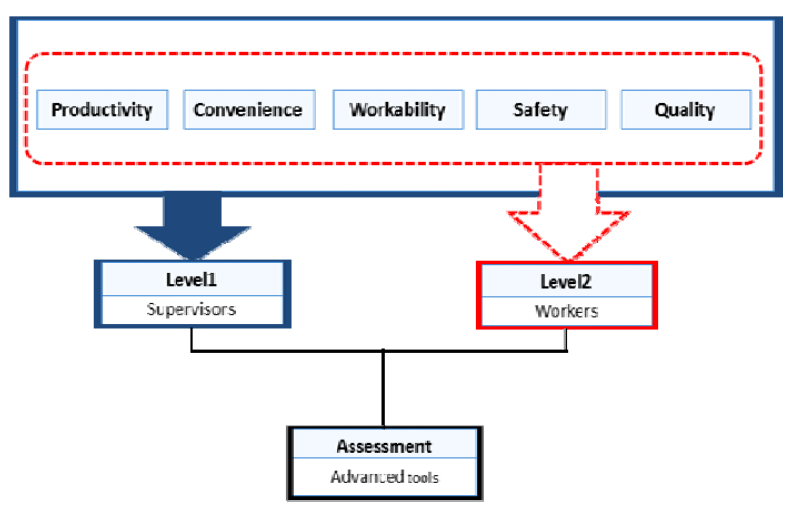

Fig. 2. Evaluation Structure Chart

The goals of the two different questionnaires are to introduce and apply advanced construction tool based on the positions of both managers and workers.

To this end, pairwise comparison of managers' weights was made; the sum of all elements should become 1.0. A survey of workers' evaluation values was made using a seven-point scale questionnaire and the values were derived using arithmeticgeometric mean. An equation through which generalization of managers' weights and workers' evaluation values may be made was applied and scores were derived for comprehensive evaluation, thereby heightening accuracy and reliability of the ModifiedAHP.

\section{Productivity Evaluation}

\section{Introduction of Advanced Tools}

The areas advanced construction tools are practically used encompass diverse areas such as construction, electricity, facility, and safety areas. The advanced construction tools evaluated in this study's questionnaires are as follows.

In order to collect opinions of managers and workers on the introduction and application of advanced construction tools, an evaluation was made by conducting a survey on the advanced construction tools and their jobs. 
Table 2. Advanced Construction Tools

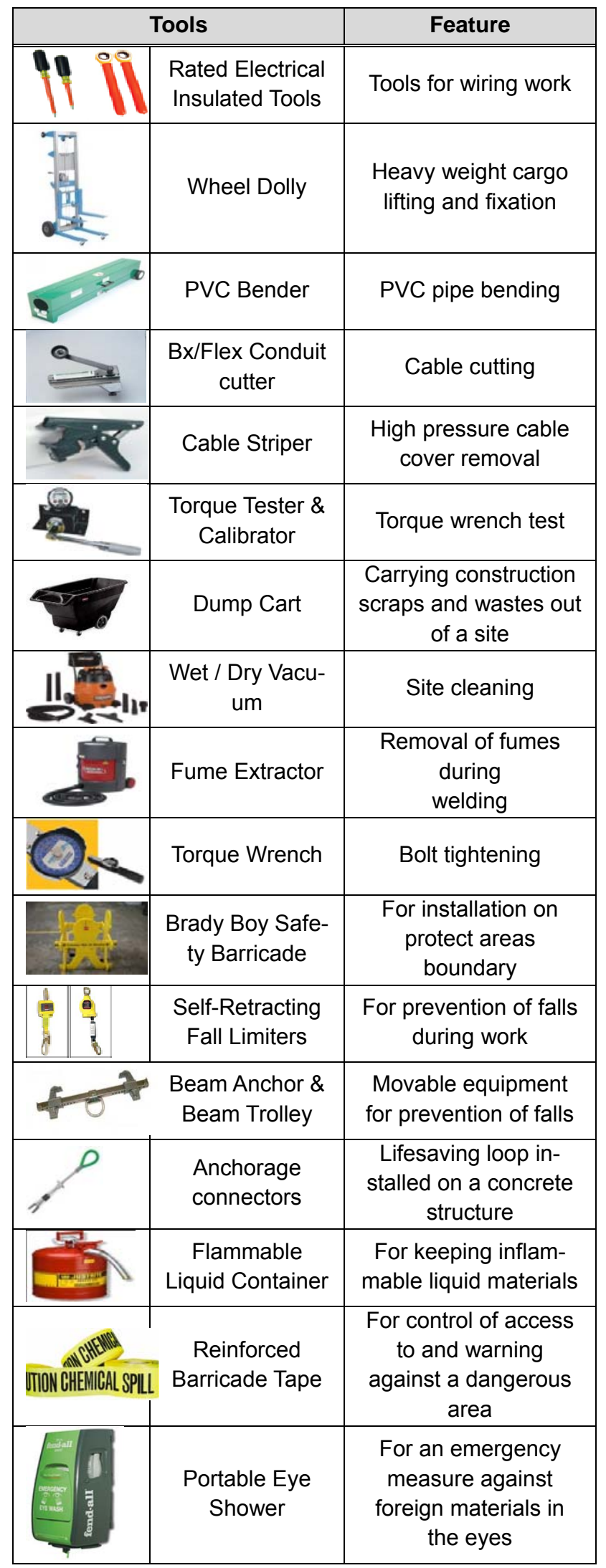

\section{Modified-AHP Survey Method}

The Modified-AHP questionnaire had two parts: one for calculation of weights managers placed importance on at the time when they decided to introduce advanced construction tools and the other for evaluation of workers' degree of satisfaction relative to existing tools.

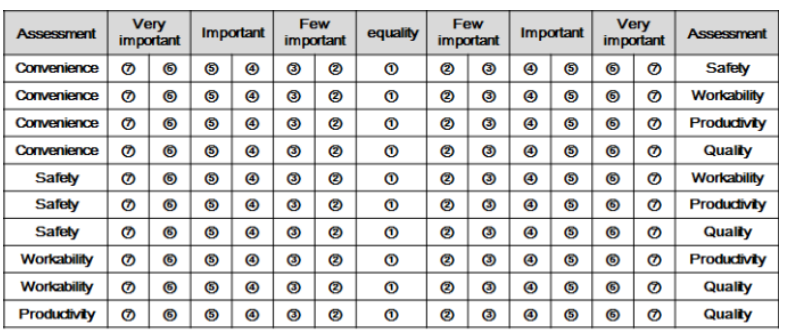

Fig.3. The Form of the Questionnaire for Managers

\begin{tabular}{|c|c|c|c|c|c|c|c|c|}
\hline \multicolumn{2}{|r|}{ Assessment } & \multicolumn{5}{|c|}{ lowness } & \multicolumn{2}{|c|}{ highness } \\
\hline \multirow{3}{*}{ Convenience } & Portable & (1) & (2) & (3) & (4) & (5) & (2) & (7) \\
\hline & Easy to store & (1) & (2) & (3) & (4) & (5) & () & (7) \\
\hline & Easy to carry & (1) & (2) & (3) & (4) & (5) & () & (7) \\
\hline \multirow{2}{*}{ Safety } & Safe for workers & (1) & (2) & (3) & (4) & (5) & () & (7) \\
\hline & Safe for related work & (1) & (2) & (3) & (4) & (5) & (6) & (7) \\
\hline \multirow{6}{*}{ Workability } & Less support works & (1) & (2) & (3) & (4) & (5) & (6) & (7) \\
\hline & Less tiresome during the work & (1) & (2) & (3) & (4) & (5) & () & (7) \\
\hline & Useful & (1) & (2) & (3) & (4) & (5) & (2) & (7) \\
\hline & Rapidly work & (1) & (2) & (3) & (4) & (5) & () & (7) \\
\hline & Easy to grip by hands & (1) & (2) & (3) & (4) & (5) & (6) & (7) \\
\hline & Comfortable & (1) & (2) & (3) & (4) & (5) & (6) & (7) \\
\hline \multirow{5}{*}{ Productivity } & Easy to prepare & (1) & (2) & (3) & (4) & (5) & (6) & (7) \\
\hline & Reduce material waste & (1) & (2) & (3) & (4) & (5) & (6) & (7) \\
\hline & Reduce time & (1) & (2) & (3) & (4) & (5) & (6) & (7) \\
\hline & Flexible for sizes & (1) & (2) & (3) & (4) & (5) & (6) & (7) \\
\hline & Helpful for succeed task & (1) & (2) & (3) & (4) & (5) & () & (7) \\
\hline \multirow{3}{*}{ Quality } & Equal quality & (1) & (2) & (3) & (4) & (5) & () & (7) \\
\hline & Less defects & (1) & (2) & (3) & (4) & (5) & (6) & (7) \\
\hline & Excellent quality for work result & (1) & (2) & (3) & (4) & (5) & (6) & (7) \\
\hline
\end{tabular}

Fig.4. The Form of the Questionnaire for Workers

Table 3. Scales for Relative Importance

\begin{tabular}{|c|c|l|}
\hline Scale & Definition & \multicolumn{1}{|c|}{ Description } \\
\hline \hline 1 & $\begin{array}{c}\text { Equally } \\
\text { important }\end{array}$ & $\begin{array}{l}\text { Two compared elements } \\
\text { have equal importance }\end{array}$ \\
\hline 5 & $\begin{array}{c}\text { Slightly im- } \\
\text { portant }\end{array}$ & $\begin{array}{l}\text { An element is slightly more } \\
\text { important than the other } \\
\text { element }\end{array}$ \\
\hline 7 & $\begin{array}{c}\text { Very } \\
\text { important }\end{array}$ & $\begin{array}{l}\text { An element is more im- } \\
\text { portant than the other }\end{array}$ \\
\hline 2.4 .6 & $\begin{array}{l}\text { important than the other } \\
\text { element } \\
\text { Middle val- } \\
\text { above scales the }\end{array}$ & $\begin{array}{l}\text { Degree of importance is } \\
\text { middle between the above } \\
\text { scales }\end{array}$ \\
\hline $\begin{array}{c}\text { recip- } \\
\text { rocal }\end{array}$ & $\begin{array}{l}\text { When the value of an ele- } \\
\text { ment } \alpha \text { against } \beta \text { is } n, \text { one } \\
\text { of the above scales, an } \\
\text { element } \beta \text { 's importance } \\
\text { against the element } \alpha \text { is } 1 / n .\end{array}$ \\
\hline
\end{tabular}

In other words, during the stage of calculating managers' weights, geometric mean based on pairwise comparison was calculated and during the stage of examining workers' degree of satisfaction with advanced construction tools, a seven-point scale was applied and arithmetic-geometric mean was calcu- 
lated in order to heighten accuracy and reliability of the analysis.

The survey on the introduction and application of advanced construction tools was conducted between September and November, 2011 by visiting construction sites where the tools had been introduced.

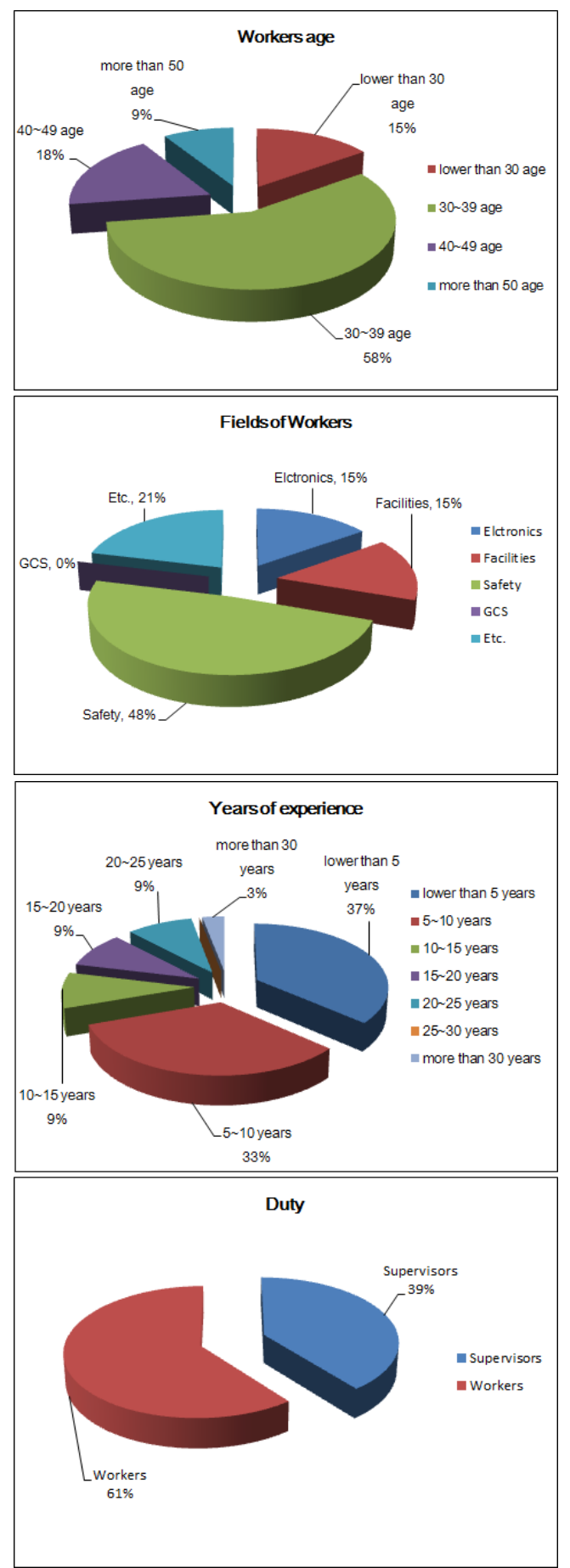

Fig. 4. Analysis Result of the Collected Questionnaires' Respondents

A total of 33 questionnaires were collected from 13 managers (39\%) and 20 workers (61\%). The safety area accounted for the largest number of respondents at $16(48 \%)$ among the areas, followed by the facility area at $5(15 \%)$, the electricity area at 5
Table 4 Managers' Weights for Each Advanced Construction Tool

\begin{tabular}{|c|c|c|c|c|c|}
\hline Tools & $\begin{array}{l}\text { Con- } \\
\text { veni } \\
\text { ence }\end{array}$ & $\begin{array}{l}\text { Safe- } \\
\text { ty }\end{array}$ & $\begin{array}{l}\text { Work } \\
\text { abil- } \\
\text { ity }\end{array}$ & $\begin{array}{l}\text { Prod } \\
\text { uctiv } \\
\text { ity }\end{array}$ & $\begin{array}{c}\text { Quali } \\
\text { ty }\end{array}$ \\
\hline $\begin{array}{c}\text { Rated } \\
\text { Electrical } \\
\text { Insulated } \\
\text { Tools }\end{array}$ & 0.074 & 0.537 & 0.110 & 0.066 & 0.213 \\
\hline $\begin{array}{c}\text { PVC } \\
\text { Bender }\end{array}$ & 0.053 & 0.348 & 0.166 & 0.137 & 0.296 \\
\hline $\begin{array}{c}\text { Bx/Flex } \\
\text { Conduit } \\
\text { Cutter }\end{array}$ & 0.092 & 0.415 & 0.094 & 0.160 & 0.239 \\
\hline $\begin{array}{l}\text { Cable } \\
\text { Striper }\end{array}$ & 0.099 & 0.287 & 0.094 & 0.074 & 0.446 \\
\hline $\begin{array}{c}\text { Torque } \\
\text { Tester \& } \\
\text { Calibrator }\end{array}$ & 0.138 & 0.284 & 0.094 & 0.085 & 0.399 \\
\hline $\begin{array}{l}\text { Wet/Dry } \\
\text { Vacuum }\end{array}$ & 0.335 & 0.157 & 0.224 & 0.101 & 0.183 \\
\hline $\begin{array}{l}\text { Fume } \\
\text { Extractor }\end{array}$ & 0.262 & 0.282 & 0.146 & 0.159 & 0.150 \\
\hline $\begin{array}{l}\text { Torque } \\
\text { Wrench }\end{array}$ & 0.084 & 0.422 & 0.139 & 0.088 & 0.267 \\
\hline $\begin{array}{c}\text { Brady Boy } \\
\text { Safety } \\
\text { Barricade }\end{array}$ & 0.147 & 0.420 & 0.109 & 0.108 & 0.216 \\
\hline $\begin{array}{c}\text { Flammable } \\
\text { Liquid } \\
\text { Container }\end{array}$ & 0.129 & 0.433 & 0.152 & 0.136 & 0.150 \\
\hline $\begin{array}{c}\text { Reinforced } \\
\text { Barricade } \\
\text { Tape }\end{array}$ & 0.214 & 0.214 & 0.220 & 0.163 & 0.189 \\
\hline $\begin{array}{l}\text { Wheel } \\
\text { Dolly }\end{array}$ & 0.262 & 0.292 & 0.234 & 0.104 & 0.109 \\
\hline Dump Cart & 0.215 & 0.221 & 0.254 & 0.258 & 0.053 \\
\hline $\begin{array}{l}\text { Anchorage } \\
\text { connectors }\end{array}$ & 0.138 & 0.515 & 0.218 & 0.045 & 0.084 \\
\hline $\begin{array}{c}\text { Self- } \\
\text { Retracting } \\
\text { Fall } \\
\text { Limiters }\end{array}$ & 0.218 & 0.273 & 0.202 & 0.180 & 0.127 \\
\hline $\begin{array}{c}\text { Beam } \\
\text { Anchor \& } \\
\text { Beam } \\
\text { Trolly }\end{array}$ & 0.194 & 0.270 & 0.189 & 0.204 & 0.144 \\
\hline $\begin{array}{l}\text { Portable } \\
\text { Eye } \\
\text { shower }\end{array}$ & 0.426 & 0.230 & 0.145 & 0.075 & 0.125 \\
\hline
\end{tabular}

(15\%), and other areas at $7(21 \%)$. Other areas included construction, paint, and interior design areas. 
The analysis result of the respondents of the 33 collected questionnaires is as follows.

Workers' evaluation values of each advanced construction tools derived using a seven-scale questionnaire and arithmetic-geometric mean are as follows.

\section{Assessment of Advanced ToOls}

A comprehensive evaluation of advanced construction tools was made, with a structure of combining managers' macroscopic insights and managers' microscopic opinions. Prior to generalization of these two levels, managers' weights and workers' evaluation values for advanced construction tools derived earlier were substituted to the equation below to derive the Modified-AHP scores.

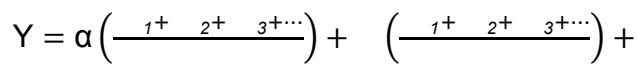

$$
\begin{aligned}
& \left(\frac{1^{+} 2^{+} 3^{+\cdots}}{3}\right)+\left(\frac{1^{+} 2^{+} 3^{+\cdots}}{1+2^{+}}\right)+ \\
& \left(\begin{array}{l}
1+2^{+}+\cdots \\
\hline
\end{array}\right)
\end{aligned}
$$

Here,

$\mathrm{Y} \leq 7.0$

$\alpha=$ Manger's weight for convenience

$\beta=$ Manger's weight for safety

$Y=$ Manger's weight for workability

$\delta=$ Manager's weight for productivity

$\varepsilon=$ Manger's weight for quality

$\mathrm{x}_{\mathrm{an}}=$ Workers' evaluation value for convenience

$x_{\beta n}=$ Workers' evaluation value for safety

$\mathrm{x}_{\mathrm{yn}}=$ Workers' evaluation value for workability

$x_{\delta n}=$ Workers' evaluation value for productivity

$x_{n}=$ Workers' evaluation value for quality

The sum of managers' weights is 1.0 and that of workers' evaluation values is 7.0 , which translates into $Y$ being 7.0. In order to derive sub-elements of workers' evaluation values for each tool, arithmeticgeometric mean was used.

The Modified-AHP score of each advanced construction tool derived by applying the above equation is as follows. Based on the overall ranks of advanced construction tools, the upper $30 \%$, the middle $40 \%$, and the lower $30 \%$ were classified into the upper, middle, and lower classes.

The study was able to look at what elements managers focused on in introducing advanced construction tools and workers did in using them by analyzing the questionnaires filled in by the managers and the workers.

Further, this study presented a relatively successful example by dividing advanced construction tools into the upper, middle, and lower classes based on the Modified-AHP scores of advanced construction tools.
Table 5. Workers' Evaluation Values of Each Advanced

\begin{tabular}{|c|c|c|c|c|c|}
\hline Tools & $\begin{array}{l}\text { Con } \\
\text { veni } \\
\text { ence }\end{array}$ & $\begin{array}{l}\text { Safe- } \\
\text { ty }\end{array}$ & $\begin{array}{c}\text { Work } \\
\text { abil- } \\
\text { ity }\end{array}$ & $\begin{array}{l}\text { Prod } \\
\text { uctiv } \\
\text { ity }\end{array}$ & $\begin{array}{l}\text { Qual } \\
\text { ity }\end{array}$ \\
\hline $\begin{array}{c}\text { Rated } \\
\text { Electrical } \\
\text { Insulated } \\
\text { Tools }\end{array}$ & 4.6 & 6.2 & 4.8 & 4.4 & 5.2 \\
\hline $\begin{array}{c}\text { PVC Bend- } \\
\text { er }\end{array}$ & 2.0 & 6.0 & 3.7 & 4.4 & 5.0 \\
\hline $\begin{array}{c}\text { Bx/Flex } \\
\text { Conduit } \\
\text { Cutter }\end{array}$ & 6.0 & 6.0 & 5.5 & 4.1 & 5.3 \\
\hline $\begin{array}{l}\text { Cable } \\
\text { Striper }\end{array}$ & 6.0 & 6.0 & 3.3 & 4.6 & 4.1 \\
\hline $\begin{array}{c}\text { Torque } \\
\text { Tester \& } \\
\text { Calibrator }\end{array}$ & 4.3 & 5.5 & 3.6 & 4.3 & 4.3 \\
\hline $\begin{array}{l}\text { Wet/Dry } \\
\text { Vacuum }\end{array}$ & 4.1 & 4.3 & 5.5 & 4.4 & 4.2 \\
\hline $\begin{array}{l}\text { Fume } \\
\text { Extractor }\end{array}$ & 4.6 & 4.1 & 5.1 & 4.4 & 4.2 \\
\hline $\begin{array}{l}\text { Torque } \\
\text { Wrench }\end{array}$ & 5.0 & 5.0 & 4.2 & 4.4 & 4.2 \\
\hline $\begin{array}{l}\text { Brady Boy } \\
\text { Safety } \\
\text { Barricade }\end{array}$ & 4.3 & 2.8 & 3.8 & 2.1 & 3.7 \\
\hline $\begin{array}{c}\text { Flammable } \\
\text { Liquid Con- } \\
\text { tainer }\end{array}$ & 4.3 & 5.8 & 3.5 & 2.9 & 3.2 \\
\hline $\begin{array}{c}\text { Reinforced } \\
\text { Barricade } \\
\text { Tape }\end{array}$ & 5.9 & 4.7 & 5.4 & 5.0 & 5.2 \\
\hline Wheel Dolly & 5.3 & 3.7 & 4.8 & 3.3 & 3.8 \\
\hline Dump Cart & 5.2 & 6.0 & 5.6 & 5.3 & 4.9 \\
\hline $\begin{array}{l}\text { Anchorage } \\
\text { connectors }\end{array}$ & 5.7 & 6.5 & 4.7 & 4.0 & 3.5 \\
\hline $\begin{array}{c}\text { Self- } \\
\text { Retracting } \\
\text { Fall } \\
\text { Limiters }\end{array}$ & 4.5 & 6.0 & 4.5 & 4.7 & 4.0 \\
\hline $\begin{array}{c}\text { Beam An- } \\
\text { chor \& } \\
\text { Beam Trolly }\end{array}$ & 4.0 & 5.5 & 4.5 & 5.1 & 6.0 \\
\hline $\begin{array}{c}\text { Portable } \\
\text { Eye shower }\end{array}$ & 6.0 & 4.0 & 4.5 & 4.0 & 4.3 \\
\hline
\end{tabular}
Construction Tool 
Table 6. Modified-AHP Score of Each Advanced Construction Tool

\begin{tabular}{|c|c|}
\hline Tools & M-AHP \\
\hline \hline Rated Electrical Insulated Tools & 5.60 \\
\hline PVC Bender & 4.89 \\
\hline Bx/Flex Conduit Cutter & 5.48 \\
\hline Cable Striper & 4.80 \\
\hline Torque Tester \& Calibrator & 4.58 \\
\hline Wet/Dry Vacuum & 4.49 \\
\hline Fume Extractor & 4.44 \\
\hline Torque Wrench & 4.62 \\
\hline Brady Boy Safety Barricade & 3.25 \\
\hline Flammable Liquid Container & 4.47 \\
\hline Reinforced Barricade Tape & 5.25 \\
\hline Wheel Dolly & 4.35 \\
\hline Dump Cart & 5.49 \\
\hline Anchorage connectors & 5.63 \\
\hline Self-Retracting Fall Limiters & 4.88 \\
\hline Beam Anchor \& Beam Trolly & 5.02 \\
\hline Portable Eye shower & 4.97 \\
\hline
\end{tabular}

Their ranks were derived based on the Modified-AHP score of each of advanced construction tools.

Table 7. Each Advanced Construction Tool's Rank

\begin{tabular}{|c|c|c|}
\hline Tools & Rank & Class \\
\hline Anchorage connectors & 1 & \multirow{5}{*}{ Upper } \\
\hline Rated Electrical Insulated Tools & 2 & \\
\hline Dump Cart & 3 & \\
\hline Bx/Flex Conduit Cutter & 4 & \\
\hline Reinforced Barricade Tape & 5 & \\
\hline Beam Anchor \& Beam Trolly & 6 & \multirow{7}{*}{ Middle } \\
\hline Portable Eye shower & 7 & \\
\hline PVC Bender & 8 & \\
\hline Self-Retracting Fall Limiters & 9 & \\
\hline Cable Striper & 10 & \\
\hline Torque Wrench & 11 & \\
\hline Torque Tester \& Calibrator & 12 & \\
\hline Wet/Dry Vacuum & 13 & \multirow{5}{*}{ Lower } \\
\hline Flammable Liquid Container & 14 & \\
\hline Fume Extractor & 15 & \\
\hline Wheel Dolly & 16 & \\
\hline Brady Boy Safety Barricade & 17 & \\
\hline
\end{tabular}

\section{Conclusions}

This study applied the Modified-AHP by focusing on how to enhance labor productivity for productivity improvement as a whole and collected opinions on each advanced construction tool from managers and workers. This study was able to figure out major elements managers and workers considered in each advanced construction tool.

However, the number of survey samples was so small, which resulted in relatively low reliability.

Therefore, future study should derive weight by categories like electricity, facilities, and safety in order to come up with measures for the introduction of each of advanced construction tools. Moreover, reliability should be heightened by increasing the number of survey samples on advanced construction tools.

\section{ACKNOWLEDGMENT}

This work was supported by the Brain Korea 21 Project and the Samsung C\&T Corporation of Construction Equipment Research Institute in 2010.

\section{REFERENCES}

1. Kim, Y.S., "Analysis of the Factors Influencing Construction Productivity", Journal of AIK, Vol. 10(10), 1994.

2. Jo, H.H., "A Study on the motion Analysis and AHP evaluation method in Construction Works", Journal of AlK, Vol. 17(2), 1997.

3. Won, J.S., "An Analysis of the International Competitiveness of Productivity in the Korea", Journal of KICEM, Vol. 9(4), 2008.

4. Lee, M.N., "Introduction, Application, and Productivity Evaluation of Advanced Tools", Proceedings of KICEM, Vol. 11, p.33, 2011. 